\title{
Effects of crumb rubber size and concentration on Marshall parameters of rubberized asphalt mixture
}

\author{
Lastik katkılı asfalt karışımındaki kırıntı lastik boyutunun ve oranın \\ Marshall parametrelerine etkileri
}

\author{
Ali ALMUSAWI ${ }^{*}$ iD , Hassan Shuaibu ABDULRAHMAN² (D), Mohammad Razeq SHAKHAN ${ }^{3}$ iD, Bora DOĞAROĞLU4 ID \\ 1,3Graduate School of Natural and Applied Sciences, Dokuz Eylul University, Izmir, Turkey. \\ ali89.engin@yahoo.com, razig.shakhan@yahoo.com \\ 2Department of Civil Engineering, Federal University of Technology Minna, Minna, Nigeria. \\ ahas92@yahoo.com \\ ${ }^{4}$ Department of Civil Engineering, Izmir Institute of Technology, Izmir, Turkey. \\ boradogaroglu@gmail.com
}

\section{Abstract}

The depletion of natural aggregate sources which generally accounts for a huge percent of Hot Mixed Asphalts (HMAs) and the difficulty posed by disposal scrap tires are a major environmental concern for the future. The use of waste products like scrap tires in highway construction is considered a sustainable way of dealing with these issues. Crumb rubber is a material pulverized from waste polymer products like scrap tires which are then added to HMAs to improve their performance. This study focuses on the sensitivity of crumb rubber particle sizes (fine $\leq 1.18 \mathrm{~mm}$ ), (coarse $\geq 1.18 \mathrm{~mm}$ and $\leq 3.35$ $\mathrm{mm}$ ) (and mix of 50\% fine and 50\% coarse) and partial replacement (1.5 and $2.5 \%$ of total weight) of aggregates on the Marshall test parameters of rubberized asphalt mixes. The Marshall test parameters: density, stability, VTM, VFB of both rubberized asphalt and conventional asphalt samples were compared and also the Asphalt Institute (AI) and National Asphalt Pavement Association (NAPA) methods were used to obtain the optimum bitumen content (OBC). From the results, it suggests that; the utilization of dry process methodology of adding crumb rubber additives in different sizes and percentages had a considerable effect on Marshal test parameters and also influences the optimum binder content estimates. The results of this study can be used as a reference point for the use of crumb rubber in HMAs.

Keywords: Crumb rubber, Marshall, Optimum bitumen content, Rubberized asphalt.

\section{Introduction}

Utilization of waste products in highway construction is considered a sustainable way of dealing with waste disposal issues and scrap tires is one of such wastes which has been well researched into with the aim of overcoming problems associated with the elastic properties of bituminous mixture and also to aid in the re-use of huge amounts of waste scrap tires. The use of scrap tires as a complementary material in the pavement industry dates back to the early 1960s. The addition of waste tires into asphalt mix was done using two fundamental processes; the wet process and dry process [1].
Öz

Genelde Bitümlü Sicak Karısım (BSK) asfaltların büyük bir yüzdesini oluşturan doğal agrega kaynakların tüketilmesi ve hurda lastiklerinin imhası gelecek için önemli çevre sorunları olușturmaktadır. Karayolu yapımında hurda lastikler gibi atık ürünlerin kullanılması, bu sorunların üstesinden gelmenin sürdürülebilir bir yolu olarak kabul edilmektedir. Kırıntı Lastik (KL), BSK'ların performansını artırmak için kullanılabilecek bir tür polimer katkı ve termoplastik elastomerdir. Bu çalısmada, kırıntı lastik büyüklüğünün ve karısımdaki doğal agrega ile kısmi değiștirilmesinin lastik katkılı asfalt karışımlarının Marshall test parametreleri üzerindeki etkisi incelenmiștir. Üc farklı boyutta kırıntı lastik kullanilmıstır; ince $(\leq 1.18 \mathrm{~mm}), \mathrm{kaba}(\geq 1.18 \mathrm{ve} \leq 33.35 \mathrm{~mm})$ ve (50/50) oraninda hem ince hem de kaba kombinasyonu. \%1,5 ve \%2,5 oranlarında olmak üzere agrega toplam ağırlı̆̆ı kısmen değistirilerek farklı yüzdelerde kırıntı Lastik kullanılmışıır. Lastik katkılı asfalt karıșımları, geleneksel asfalt karısımıyla karșılastırılmıstır. Optimum bitüm içeriği Asfalt Enstitüsü (AI) ve Ulusal Asfalt Kaplama Derneği (NAPA) yöntemleri kullanılarak belirlenmiștir. Kuru ișlem metodolojisi uygulanarak farklı ebatlarda ve yüzdelerde kırıntı lastik katkı maddesi eklenmesi Marshall test parametreleri üzerinde önemli bir etkiye sahiptir ve ayrıca Asfalt Enstitüsü ve Ulusal Asfalt Kaplama Derneği yöntemleri ile belirlenen optimum binder (bağlayıcı) içeriği tahminlerini etkilemektedir. Bu çalıșmanın sonuçları BSK'larda kırıntı lastik kullanımı için bir referans olarak kullanılabilir.

Anahtar kelimeler: Lastik kırıntısı, Marshall, Optimum bitüm içeriği, Lastik katkılı asfalt.

The addition of a small quantities of ground rubber from discarded tires as a substitute for a part of the mineral aggregate in the mixture is termed as "dry process". On the other hand, mixing grounded scrap tire with bitumen and allowing it to react for a period of $45 \mathrm{~min}$ to an hour improves the engineering properties of the bitumen the process came to be known as "wet process" [1].

Many researches have been undertaken using both wet and dry processes and in a particular research, the author evaluated the effect of rubber and bitumen contents on different engineering properties of rubberized asphalt mixture, containing $0 \%, 5 \%$, $10 \%$ and $15 \%$ waste ground rubber tire powder (WGRTP) and $4.5 \%, 5 \%$ and $5.5 \%$ asphalt by weight of total mix and he found that the rubberized asphalt mix containing $5 \%$ bitumen and $5 \%$

${ }^{*}$ Corresponding author/Yazışılan Yazar 
rubber contents improved the various mechanical properties of the mix more than the other contents [2]. In a similar research, crumb rubber was added in terms of percentages (1\% and $2 \%)$ and sizes (number 40 and 80 ) to bituminous mixtures using the wet process and the results were positive as they were all within standard specification and most importantly, they tend to increase the strength and stability of the mix [3].

From literature, the performances of asphalt mixtures modified with crumb rubber through both processes tend to improve the properties of the mix.

Mahta et al. [4] investigated the effect of rubber in different sizes on rutting performance of HMA. The obtained results showed that the coarse rubber particles increased the resistance against the permanent deformation as the percentage of rubber increased up to $3.5 \%$. Airey evaluated the mechanical properties of crumb rubber using dry process. The results identified a reduction in asphalt mixture stiffness about $25 \%$ for the 3\% CRM asphalt mixture and approximately of $45 \%$ for the 5\% CRM asphalt mixture [5].

In general, the cost of rubber modified asphalt mixture is relatively high, but the extension of the service life has saved the cost of maintenance in the long term [6]. Also, it reduces a lot of hazardous since waste tires are used which could have been a big issue on the environment. On the hand, the utilization of crumb rubber in the dry procees may have a direct effect on the performance of the asphalt mixtures in term of reduction stiffness and the rutting resistance [5]. The wet process has the advantage of controlling the binder properties but it requires special machinery to prepare the bitumen and rubber blend while the dry process is not consistent as it is influenced by mixing process, binder types, rubber content, and aggregate gradation and is relatively less popular because it requires specially graded aggregate to accommodate the scrap tire crumbs which tends to increase cost of production as well. Also, some authors mentioned other factors as a disadvantage of this method especially pavement surface defects like cracking and raveling [7]-[10]. It is expected that using the dry process in making rubberized asphalt should have a greater environmental impact since the rubber particles supposedly replace aggregate only and the reaction between the crumb rubber and bitumen should be negligible. Therefore, a higher percentage replacement of crumb rubber may affect the stability of the asphalt mixes especially for highly trafficked road pavements. This work aims to determine the extent to which the size and percentage of grounded rubber affect the Marshal properties and also optimum bitumen content of asphalt mixtures using a dry process method at lower percentages of crumb rubber addition. For the dry process the crumb rubber percentage used can be from 1 to $6 \%$ by weight of the total mixture. Though, the optimum and recommended percentage is 1 to $3 \%$ [11].

\section{Experimental}

\section{$2.1 \quad$ Materials}

The type of base bitumen used in this study was an 80/100 penetration grade. To measure the properties of the bitumen, different test methods such as penetration test (ASTM D506), softening point test (ASTM D36-95), and viscosity test (ASTM D4402) have been conducted. The test results are presented in Table 1.

The aggregate type utilized in this study was Crushed granite aggregate. The maximum nominal aggregate size was $14 \mathrm{~mm}$
(AC14) and the gradation limit was specified based on the Malaysian Public Works Department (PWD) specification [8]. The aggregate gradation is illustrated in Table 2.

Table 1. Properties of the base bitumen.

\begin{tabular}{cccc}
\hline Test & Specification & Result & $\begin{array}{c}\text { Specification } \\
\text { limits }\end{array}$ \\
\hline $\begin{array}{c}\text { Penetration } \\
\left(25^{\circ} \mathrm{C} ; 0.1 \mathrm{~mm}\right)\end{array}$ & ASTM D5 & 82 & $80-100$ \\
$\begin{array}{c}\text { Softening point }\left({ }^{\circ} \mathrm{C}\right) \\
\text { Ductility }\end{array}$ & ASTM D36 & 45 & $45-52$ \\
$\quad$ ASTM D113 & 180 & Min 100 \\
$\quad\left(25^{\circ} \mathrm{C} ; \mathrm{cm}\right)$ & & & \\
Viscosity & ASTM D4402 & 300 & - \\
$\left(135^{\circ} \mathrm{C} ; \mathrm{mPa} \cdot \mathrm{s}\right)$ & & & \\
Flash point $\left({ }^{\circ} \mathrm{C}\right)$ & ASTM D92 & 252 & 250 min \\
$\begin{array}{c}\text { Penetration } \\
\text { index }(\mathrm{PI})\end{array}$ & - & -2.23 & - \\
Specific gravity & ASTM D70 & 1.03 & 1.03 \\
\hline
\end{tabular}

Table 2: Gradation limits for asphalt concrete, AC14.

\begin{tabular}{ccc}
\hline $\begin{array}{c}\text { Sieve size } \\
(\mathrm{mm})\end{array}$ & $\begin{array}{c}\text { Percentage passing } \\
(\%)\end{array}$ & $\begin{array}{c}\text { Selected gradation } \\
(\%)\end{array}$ \\
\hline 20 & 100 & 100 \\
14 & $90-100$ & 95 \\
10 & $76-86$ & 81 \\
5 & $50-62$ & 56 \\
3.35 & $40-54$ & 47 \\
1.18 & $18-34$ & 26 \\
0.425 & $12-24$ & 18 \\
0.15 & $6-14$ & 10 \\
0.075 & $4-8$ & 6 \\
\hline
\end{tabular}

The crumb rubber was generated by scraping old truck tires at room temperature. The density of the rubber is approximately $1.15 \mathrm{~g} / \mathrm{cm}^{3}$. Several sizes of crumb rubber were used (fine $\leq 1.18 \mathrm{~mm}$ ), (coarse $\geq 1.18 \mathrm{~mm}$ and $\leq 3.35 \mathrm{~mm}$ ) (and mix of $50 \%$ fine and $50 \%$ coarse). Different percentages of crumb rubber used $(1.5$, and $2.5 \%)$ of the total weight of the aggregate.

\subsection{Test methods}

\subsubsection{Marshall mix design}

\subsubsection{Optimum bitumen content (OBC)}

There are two common methods used to determine the optimum bitumen content. The first method is according to the National Asphalt Pavement Association method (NAPA) procedure. In this method, the optimum bitumen content is the value corresponding to a $4 \%$ air void. The second method is the Asphalt Institute (AI) method. According to this method, the optimum bitumen content is the average value of the bitumen content at the maximum stability, the maximum density, and the bitumen content that corresponds to a $4 \%$ air void [9],[10]. In this study, the above two mentioned methods, NAPA and AI, have been used to determine the $\mathrm{OBC}$ for rubberized asphalt mixtures.

\subsubsection{Density}

The density plays an important role in asphalt mixture performance. In other words, any increase in density during the construction, especially during the compaction stage, will increase the shear strength of the asphalt mixture to resist the application of the repeated loads. In the Marshall Mix design method, the density changes with the bitumen content. The bitumen content has a direct effect on the density. Noticed that increasing the bitumen content will increase the mixture density until it reaches the peak value and then starts to decrease. This is attributed to the asphalt film thickness developing around the aggregate particles [12],[13]. 


\subsubsection{Voids in total mix (VTM)}

The total air voids in the mixture (VTM) have an opposite relationship with the bitumen content. In other words, the more the bitumen content in the asphalt mixture, the lesser the VTM value measured from the Marshall mix design and vice versa. Most agencies proposed VTM value range between 3 to 5 percent. Low VTM content reduces the aging effect of the asphalt film and also minimize the potentiality of the water to penetrate through the asphalt mixture. On the other side, constructing asphalt pavement with very low air content may lead to bitumen bleeding or flushing on the pavement surface [12],[13].

\subsubsection{Voids filled with bitumen (VFB)}

VFB is representing the percentage of the VMA that is filled with bitumen. Most agencies specify the VFB range lies between 75 to $85 \%$. The VFB criterion has a major role in the asphalt mixture in minimizing the susceptible to rutting under repeated traffic loads. The VFB is sensitive to the bitumen content in which any increase in the bitumen content will increase the VFB and vice versa [12],[13].

\subsubsection{Stability}

Marshall stability can be described as the maximum compressive load that a compacted Marshall specimen can endure before it breaks at $60{ }^{\circ} \mathrm{C}$ and a loading rate of 51 $\mathrm{mm} / \mathrm{min}$. Marshall stability measures the mass viscosity of the aggregate bitumen mixture. The Stability values can be increased by using a more viscous bitumen such as a higher penetration grade bitumen or polymer modified bitumen. Also, utilizing more angular aggregate for the asphalt mixture may yield high stability value. Small Marshall values may result in deformation of the asphalt pavement and clearly can be noticed in the permanent deformation (rutting) generating on the asphalt pavement surface. Marshall stability is governed by the weather temperature, load configuration, amount of load, tire pressures, sub-grade material properties, and other factors [12],[13].

\section{Results and discussion}

\subsection{Determination of optimum bitumen content (OBC):}

Optimum bitumen content (OBC) for AC14 was determined by using trial bitumen contents of $4 \%, 4.5 \%, 5.0 \%, 5.5 \%$, and $6.0 \%$. Data obtained were analyzed using Marshall properties. Figure 1 summarizes the result of Marshall mix design for conventional and rubberized mixtures of AC14. Results indicate that crumb rubber affects the optimum bitumen content. The optimum bitumen content increase with the amount of crumb rubber added to mixture. This behavior could be attributed to the absorption of bitumen by the crumb rubber which increases the OBC. Also, for all samples, the determined optimum bitumen content through NAPA method is lesser than the AI method.

\subsection{Density analysis}

Figures 2-4 illustrate the relationship between density and bitumen content. The figures show that with increasing crumb rubber percentage added to the mixture, the density value decreases. All Rubber modified mixtures tend to be less dense than the conventional asphalt mixtures. The elasticity property of the crumb rubber added to the mixture is responsible for the reduction in the compaction effectiveness of the mixture. Thus, All Rubber modified mixtures have lower density compared to the conventional mixture. The difficulty to achieve the target density after compaction is because the mixtures tend to expand due to the actions of rubber particles that bounce back to original shape after being extruded from the mold and push all the surrounding materials, thus increase the volume of air voids. Therefore, in order to achieve the same target air voids as the conventional mixture more compaction effort is needed for the rubberized mixtures.

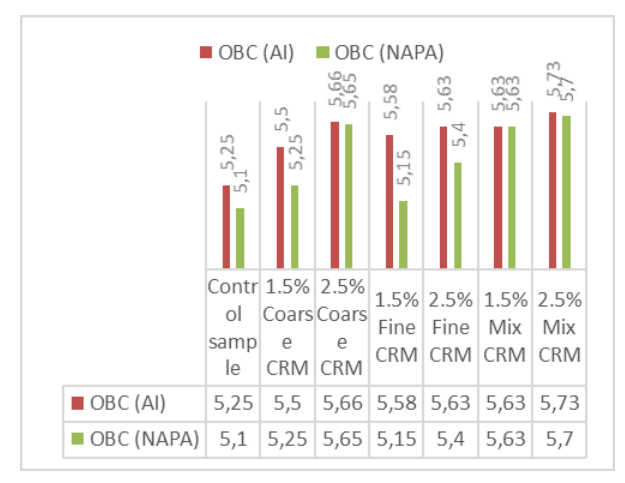

Figure 1. Optimum binder content for different mixes.

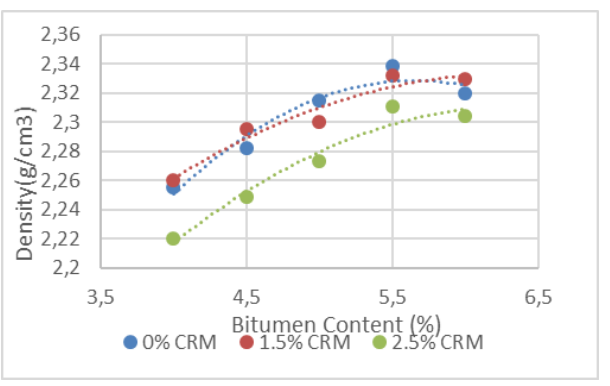

Figure 2. Density analysis for different mixture types (Coarse CRM).

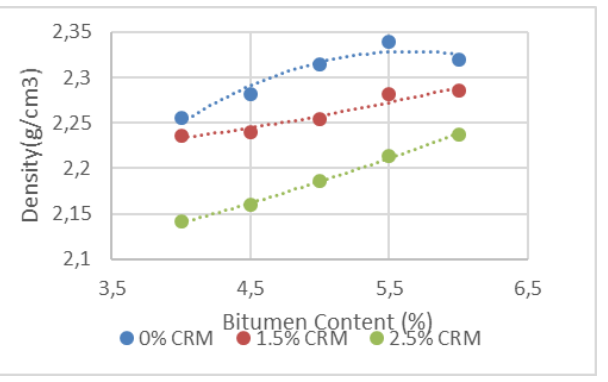

Figure 3. Density Analysis for Different Mixture Types (Fine CRM).

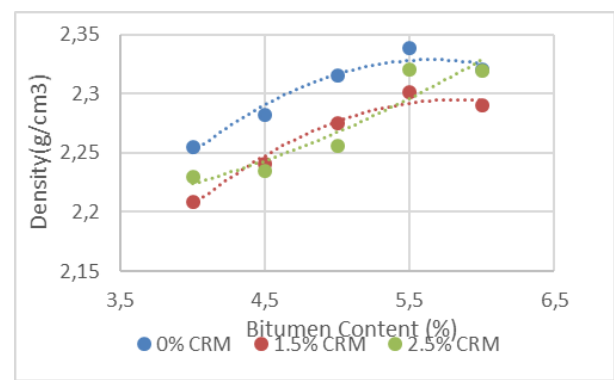

Figure 4. Density analysis for different mixture types (Mix CRM). 


\subsection{Voids in Total Mix analysis (VTM)}

Figures 5-7 show the relationships between VTM and bitumen content for different rubber sizes. It was found that the trend of the VTM obtained decrease with the increase in the bitumen content. The higher the rubber content added to the mixture, the higher the air voids content measured after the compaction. Similar trend almost similar for all rubber sizes. However interesting observation can be found for specimen modified with fine crumb rubber that the total air voids achieved lower than the rest. This shows that better compaction can be achieved when fine crumb rubber is added to the mixture.

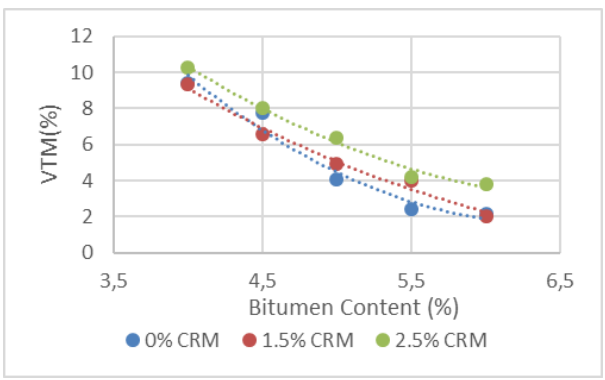

Figure 5. Voids in total mix analysis for different mixture types (Coarse CRM).

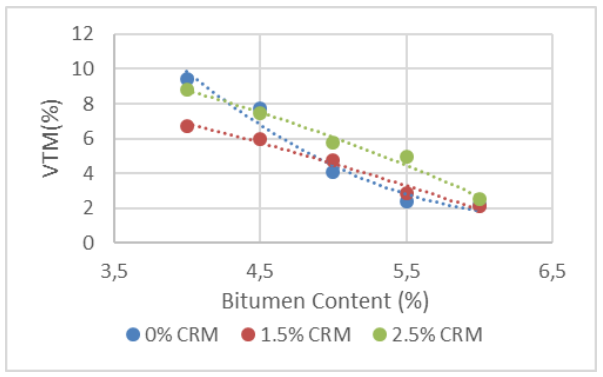

Figure 6. Voids in total mix analysis for different mixture types (Fine CRM).

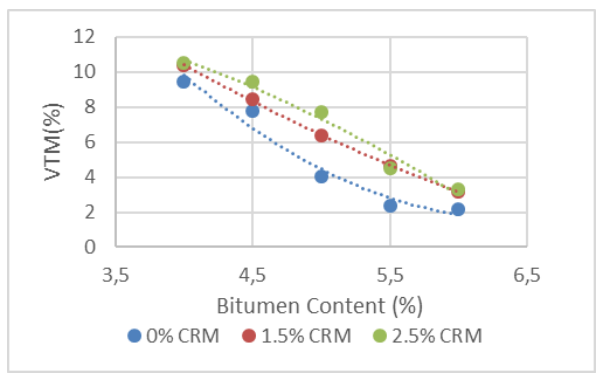

Figure 7. Voids in total mix analysis for different mixture types (Mix CRM).

\subsection{Voids Filled with Bitumen Analysis (VFB)}

Figures 8-10 illustrate the graph of VFB versus bitumen content. The result shows that the value of VFB decreases with the increase in the rubber content which could be due to the bitumen absorption by the rubber particles as a result of rubber-bitumen interaction. This is interaction was found higher in rubberized mixture modified with fine rubber as indicated by the lowest VFB. The higher surface area of the fine rubber particles seems to generate more reaction between the rubber and bitumen thus absorbs more bitumen compared to the coarse rubber.

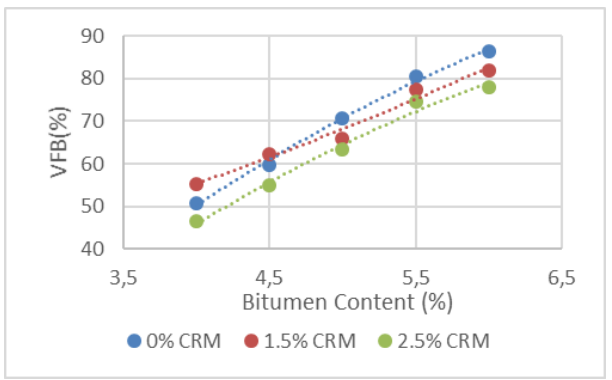

Figure 8. Voids filled with bitumen analysis for different mixture types (Coarse CRM).

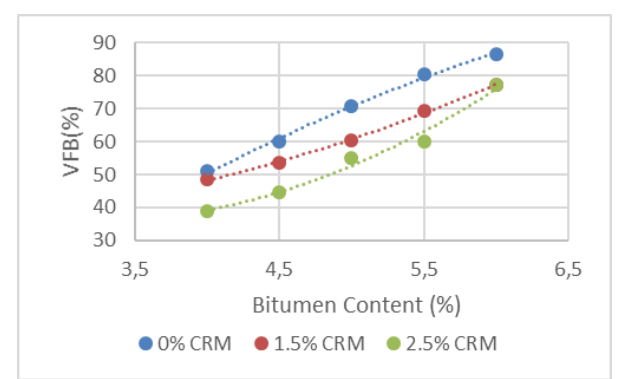

Figure 9. Voids filled with bitumen analysis for different mixture types (Fine CRM)

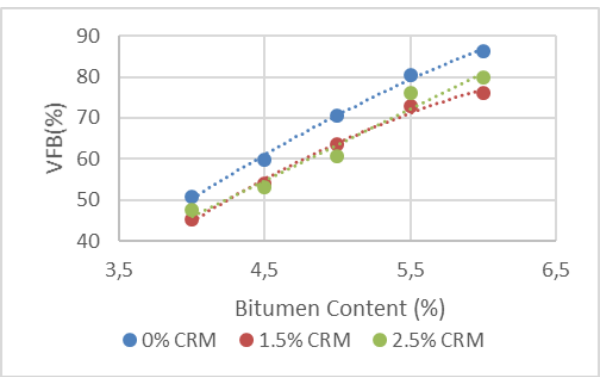

Figure 10. Voids Filled with Bitumen Analysis for different mixture types (Mix CRM).

\subsection{Stability analysis}

Figures 11-13 illustrate the Marshall Stability versus bitumen content. The figures depict that the stability value decreases progressively with the increase in the added percentage of crumb rubber mixed with aggregate. The property of bitumen cohesion affects the stability of the mixture. Cohesion results from the bonding ability of bitumen and it increases with the increase in the bitumen content.

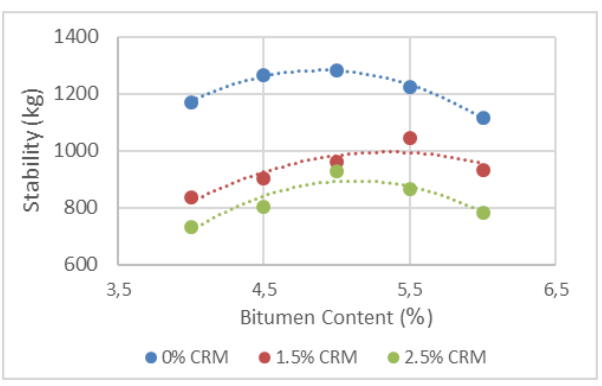

Figure 11. Stability analysis for different mixture types (Coarse CRM). 


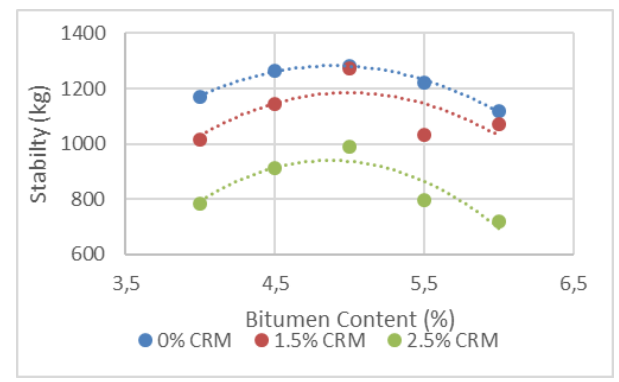

Figure 12. Stability analysis for different mixture types (Fine CRM).

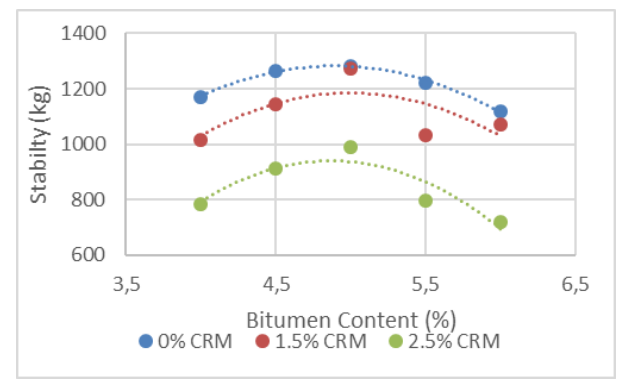

Figure 13. Stability analysis for different mixture types (Mix CRM).

However, high stability value will cause an instability problem. In other words, a high stability value will produce an asphalt pavement that is too stiff and less durable. It can be noticed that there is a clear reduction in stability value with rubber addition compare to the conventional mixture. This could be contributed to the elastic properties of the crumb rubber particles.

\section{Conclusion}

In this study, the utilization of dry process methodology for adding crumb rubber additives in different sizes and percentages had a considerable effect on Marshal test parameters and also influences the optimum binder content estimates from AI and NAPA methods. These effects are listed below;

1. The obtained Marshall parameters shows that, the stability and density are considerably decreased with the increase in the crumb rubber percentages. These results agree with most researches similar to this work. For density of the rubberized asphalt mix; crumb rubber has an elastic behavior and may be less than aggregate which might hinder the densification of the mass through compaction and thereby lowering density of the mix when compared to the conventional mixture. Therefore, it may be interesting to use higher compaction efforts. Also, the stability of asphalt mixtures depends on bitumen cohesion and crumb rubber tends to reduce the stability of the asphalt mix which may be due to the elastic properties of the rubber particles, thus it is recommended that caution be exercised when adding the crumb rubber particles as additives since too much of it may lower the stability of the mix,

2. In other marshal test properties based on volumetric analysis, it was found that the higher the rubber content added to the mixture, the higher the air voids content measured after the compaction (VTM). Similar trends were observed for all rubber sizes used. But with fine crumb rubberized asphalt, the total air voids achieved was lower than the rest. This shows that better compaction can be achieved by adding fine crumb rubber when compared the coarse and mixed crumb rubber additions. Similarly, the results obtained shows that the value of VFB decreases with the increase in the rubber content which could be due to the bitumen absorption by the rubber particles as a result of rubber-bitumen interaction. Therefore, care must be taken to avoid such asphalt mixtures that may tend to have a susceptible to rutting under the repeated loading because of the interaction between crumb rubber and bitumen,

3. Finally, on the Optimum Binder Content (OBC), two methods were used AI and NAPA methods. Even though the determined optimum bitumen content using NAPA method is lesser than the AI method, the OBC increases with increase in crumb rubber percentages added to the mixture for both. This behavior could be attributed to the absorption of bitumen by the crumb rubber which increases the $\mathrm{OBC}$.

\section{References}

[1] Epps JA. "Uses of Recycled Rubber Tires in Highways". Transportation Research Board, Washington, USA, 198, 1994.

[2] Abusharar SW. "Laboratory evaluation of rubberized asphalt using the dry process". Journal of MultiDisciplinary Science and Technology, 3(5), 4815-4820, 2016.

[3] Wulandari PS, Tjandra D. "Use of crumb rubber as an additive in asphalt concrete mixture". Procedia engineering, 171, 1384-1389, 2017.

[4] Mehta Y, Jahan K, Laicovsky J, Miller L, Parikh D, Lozano, AL. "Evaluation of the effect of coarse and fine rubber particles on laboratory rutting performance of asphalt concrete mixtures. Journal of Solid Waste Technology and Management, 30(2), 112-120, 2004.

[5] Airey GD, Singleton TM, Collop AC. "Properties of polymer modified bitumen after rubber-bitumen interaction". Journal of Materials in Civil Engineering, 14(4), 344-354, 2002.

[6] Summers CJ. "Modified Bitumen and Bituminous Materials. The Idiots Guide to Highways Maintenance, 2000". https://docplayer.net/38177789-The-idiotsguide-to-highway-maintenance.html (12.01.2019).

[7] Amirkhanian SN. "Utilization of Crumb Rubber in Asphaltic Concrete Mixtures-South Carolina Experience". South Carolina Department of Transportation, South Carolina, USA, 29634-0911, 2001.

[8] Fager GA. "Asphalt Rubber: A Summary of the use of crumb rubber in hot mixes". Transportation Research Board, Washington, USA, FHWA-KS-01-1, 2001.

[9] Hunt L. "Crumb Rubber Modified Asphalt Concrete in Oregon". Oregon Department of Transportation, Oregon, USA, FHWA-OR-RD-02-13, 2002.

[10] Malaysian PWD. "Standard specification for road works". Jabatan Kerja Raya, Kuala Lumpur, 2008.

[11] Shen J, Li B, Xie Z. "Interaction between crumb rubber modifier (CRM) and asphalt binder in dry process". Construction and Building Materials, 149, 202-206, 2017.

[12] Asphalt I. The Asphalt Handbook. $7^{\text {th }}$ ed. Kentucky, USA, Asphalt Institute, Lexington, 2007.

[13] Roberts FL, Kandhal PS, Brown ER, Lee DY, Kennedy TW. Hot Mix Asphalt Materials, Mixture Design and Construction. $2^{\text {nd }}$ ed. Maryland, USA, Lanham, 1996. 